\title{
List apostolski Papieża Franciszka Scripturae Sacrae affectus w XVI stulecie śmierci św. Hieronima
}

\section{W XVI stulecie śmierci św. Hieronima}

Umiłowanie Pisma świętego, żywa i głęboka miłość spisanego słowa Bożego, to dziedzictwo, jakie św. Hieronim pozostawił Kościołowi poprzez swoje życie i dzieła. Szesnaście wieków od śmierci świętego, te wyrażenia zaczerpnięte $\mathrm{z}$ jego liturgicznego wspomnienia ${ }^{1}$ dają nam klucz niezbędny do zrozumienia jego wybitnej postaci w dziejach Kościoła i jego wielkiego umiłowania Chrystusa. Ta miłość rozlewa się, jak rzeka w wielu potokach, w jego dziele niestrudzonego uczonego, tłumacza, egzegety, głębokiego znawcy i namiętnego propagatora Pisma świętego; wyśmienitego interpretatora tekstów biblijnych; żarliwego i niekiedy porywczego obrońcy prawdy chrześcijańskiej; ascetycznego i bezkompromisowego eremity, jak również doświadczonego przewodnika duchowego, w jego wielkoduszności i czułości. Dziś, dla nas, chrześcijan dwudziestego pierwszego wieku, żyjących tysiąc sześćset lat później, jego postać jest nadal bardzo aktualna.

\section{Wprowadzenie}

Hieronim zakończył bieg swego życia ziemskiego 30 września 420 roku w Betlejem, w założonej przez siebie wspólnocie przy Grocie Narodzenia Pańskiego. W ten sposób powierzył siebie temu Panu, którego zawsze poszukiwał i poznawał w Piśmie świętym, temu samemu, którego jako Sędziego już spotkał, rozgorączkowany, w pewnej wizji, być może w Wielkim Poście 375 roku. W tym wydarzeniu, które stanowiło decydujący punkt zwrotny w jego

1 „Boże, Ty dałeś świętemu Hieronimowi żywe i głębokie umiłowanie Pisma świętego, spraw, aby Twój lud obficie karmił się Twoim słowem i znajdował w nim źródło życia”, Kolekta Mszy św., wspomnienie św. Hieronima: Mszał rzymski, Poznań 1986. 
życiu, moment nawrócenia i zmiany perspektywy, poczuł się postawiony przed trybunałem Sędziego: „Zapytany o stan swój, odpowiedziałem, że jestem chrześcijaninem. A ów, który siedział na przedzie, rzekł: «Kłamiesz! Jesteś cyceronianinem, nie chrześcijaninem»"2. Istotnie, od najmłodszych lat Hieronim miłował czyste piękno klasycznych tekstów łacińskich, w porównaniu z którymi pisma biblijne zdawały się mu początkowo surowe i niegramatyczne, zbyt szorstkie jak na jego wyrafinowany gust literacki.

Ten epizod jego życia sprzyja decyzji, by całkowicie oddać się Chrystusowi i Jego słowu, poświęcając swoje życie na czynienie Bożych pism bardziej dostępnymi dla innych, poprzez swą niestrudzoną pracę tłumacza i komentatora. To wydarzenie nadaje jego życiu nowy, bardziej zdecydowany kierunek: stawać się sługą słowa Bożego, zakochanym w „ciele Pisma świętego". Tak więc, w nieustannym poszukiwaniu charakteryzującym jego życie, udoskonala swoje młodzieńcze studia i formację otrzymaną w Rzymie, na nowo porządkując swoją wiedzę w najbardziej dojrzałej służbie Bogu i wspólnocie kościelnej.

$\mathrm{Z}$ tego względu św. Hieronim staje się jedną $\mathrm{z}$ wielkich postaci starożytnego Kościoła, w okresie nazywanym złotym wiekiem patrystyki, prawdziwym mostem między Wschodem a Zachodem: jest przyjacielem z młodości Rufina z Akwilei, spotyka Ambrożego i prowadzi bogatą korespondencję z Augustynem. Na Wschodzie zna Grzegorza z Nazjanzu, Dydyma Aleksandryjskiego, Epifaniusza z Salaminy. Chrześcijańska tradycja ikonograficzna czyni go świętym, ukazując go wraz z Augustynem, Ambrożym i Grzegorzem Wielkim, wśród czterech wielkich doktorów Kościoła Zachodniego.

Już moi poprzednicy zechcieli w różnych okolicznościach przypomnieć jego postać. Sto lat temu, w piętnaste stulecie jego śmierci, Benedykt XV poświęcił mu encyklikę Spiritus Paraclitus (15 września 1920 r.), przedstawiając go światu jako doctor maximus explanandis Scripturis ${ }^{3}$. W ostatnich latach Benedykt XVI ukazał w dwóch kolejnych katechezach jego osobowość i twórczość ${ }^{4}$. Obecnie, w szesnaste stulecie jego śmierci, ja również pragnę przypomnieć św. Hieronima i aktualność jego przesłania i nauki, zaczynając od jego wielkiego umiłowania Pisma świętego.

Zatem można go przedstawić w doskonałym powiązaniu, jako pewnego przewodnika i uprzywilejowanego świadka, z XII Zgromadzeniem

Hieronymus, Ep. 22, 30, CSEL 54, 190.

AAS 12 (1920) s. 385-423.

4 Por. Audiencje Generalne z 7 i 14 listopada 2007, „L'Osservatore Romano” wyd. polskie 299 (2008) s. 50-52. 
Synodu Biskupów, poświęconym słowu Bożemu ${ }^{5}$, oraz z adhortacją apostolską Verbum Domini (VD) mojego poprzednika Benedykta XVI, wydaną właśnie we wspomnienie Świętego, 30 września 2010 roku $^{6}$.

\section{Z Rzymu do Betlejem}

Życie i osobisty szlak św. Hieronima przebiegają drogami Cesarstwa Rzymskiego, między Europą a Wschodem. Urodzony około 345 roku w Strydonie, na granicy Panonii z Dalmacją, na terenie dzisiejszej Chorwacji lub Słowenii, otrzymuje solidne wykształcenie w rodzinie chrześcijańskiej. Według ówczesnego zwyczaju zostaje ochrzczony jako dorosły, będąc studentem retoryki w Rzymie, w latach 358-364. To właśnie w tym okresie staje się nienasyconym czytelnikiem klasyki łacińskiej, studiującym pod okiem najwybitniejszych mistrzów ówczesnej retoryki.

Po ukończeniu studiów odbywa długą podróż do Galii, która prowadzi go do cesarskiego miasta Trewir, znajdującego się obecnie w Niemczech. To właśnie tam po raz pierwszy spotyka się ze wschodnim doświadczeniem monastycznym, szerzonym przez św. Atanazego. W ten sposób dojrzewa głębokie pragnienie, które towarzyszy mu w Aquilei, gdzie wraz z kilkoma przyjaciółmi inicjuje „,chór błogosławionych”, okres życia wspólnego.

Około roku 374, przemierzając Antiochię, postanawia udać się na pustynię Chalkis, aby praktykować w coraz bardziej radykalny sposób życie ascetyczne, w którym wiele miejsca przeznacza na naukę języków biblijnych, najpierw greckiego, a następnie hebrajskiego. Powierza się pewnemu bratu pochodzenia żydowskiego, który został chrześcijaninem i wprowadza go w poznanie nowego języka hebrajskiego i dźwięków, które nazywa „syczącymi i przydechowymi"s.

Wraz z późniejszym życiem eremity, Hieronim wybiera pustynię w jej najgłębszym znaczeniu: jako miejsce fundamentalnych wyborów egzystencjalnych, intymności i spotkania z Bogiem, gdzie poprzez kontemplację, doświadczenia wewnętrzne, walkę duchową dochodzi do poznania kruchości, z większą świadomością ograniczeń własnych i innych ludzi,

5 Synod Biskupów, Orędzie do Ludu Bożego XII Zwyczajnego Zgromadzenia Ogólnego Synodu Biskupów (4 października 2008), „L'Osservatore Romano” wyd. polskie 309 (2009) s. 24 nn.

6 Por. AAS 102 (2010) s. 681-787.

7 Hieronymus, Chronicum 374, PL 27, 697-698.

8 Hieronymus, Ep. 125, 12, CSEL 56, 131. 
doceniając znaczenie łez . Tak na pustyni dostrzega konkretną obecność Boga, konieczność relacji człowieka z Nim, Jego miłosierne pocieszenie. W tym kontekście chciałbym przypomnieć anegdotę z tradycji apokryficznej. Hieronim pyta Pana Boga: „Czego chcesz ode mnie?” - On odpowiada: ,Jeszcze nie dałeś mi wszystkiego”. — „Ale Panie, dałem ci to, i to i tamto...” — „Czegoś brakuje”. — „Czego?” — „Daj mi twoje grzechy, abym mógł mieć radość przebaczenia ich na nowo"10.

Odnajdujemy go w Antiochii, gdzie został wyświęcony na kapłana przez biskupa Paulina, następnie w Konstantynopolu, około 379 roku, gdzie poznaje Grzegorza z Nazjanzu i gdzie kontynuuje studia, poświęca się thumaczeniu z języka greckiego na łacinę ważnych dzieł (Homilie Orygenesa i Kronikę Euzebiusza z Cezarei), oddycha atmosferą Soboru, który odbywał się w tym mieście w 381 roku. W tych latach, to właśnie w studium ujawniają się jego pasja i szczodrość. To błogosławiony niepokój, który prowadzi go i sprawia, że jest niestrudzony i pełen pasji w swoich badaniach: „Ile razy zwątpiłem, ile razy ustawałem i z gorącego pragnienia, żeby się nauczyć, znów zaczynałem”, prowadzony przez ,gorzkie nasienie" takich studiów do zbierania „słodkich owoców"

W 382 roku Hieronim powraca do Rzymu, oddając się do dyspozycji papieża Damazego, który docenia jego wielkie zalety i czyni go swoim bliskim współpracownikiem. Hieronim prowadzi tu nieustanną działalność, nie zapominając o wymiarze duchowym: na Awentynie, dzięki wsparciu rzymskich arystokratek, takich jak Marcella, Paula i jej córka Eustochium, pragnących radykalnych wyborów ewangelicznych, tworzy krąg oparty na lekturze i dokładnym studiowaniu Pisma świętego. Hieronim jest egzegetą, nauczycielem, przewodnikiem duchowym. W tym okresie podejmuje się rewizji wcześniejszych łacińskich tłumaczeń Ewangelii, być może także innych części Nowego Testamentu; kontynuuje pracę jako tłumacz homilii i komentarzy biblijnych Orygenesa, prowadzi niezwykle żywą działalność epistolarną, toczy publiczne spory z autorami heretyckimi, czasami dopuszczając się przesady i nieumiarkowania, ale zawsze szczerze poruszony pragnieniem obrony prawdziwej wiary i depozytu Pisma świętego.

Ten intensywny i owocny okres zostaje przerwany przez śmierć papieża Damazego. Hieronim, zmuszony do opuszczenia Rzymu, w towarzystwie idących za nim przyjaciół i niektórych kobiet, pragnących konty-

9 Por. Hieronymus, Ep. 122, 3, CSEL 56, 63.

10 Por. Homilia w Domu Św. Marty (10 grudnia 2015). Anegdota jest cytowana w: A. Louf, Sotto la guida dello Spirito, Magnano 1990, s. 154-155.

11 Por. Hieronymus, Ep. 125, 12, CSEL 56, 131. 
nuować rozpoczęte przez niego doświadczenia duchowe i studia biblijne, wyjeżdża wpierw do Egiptu — gdzie spotyka wielkiego teologa Dydyma Aleksandryjskiego - a następnie do Palestyny, aby ostatecznie osiedlić się w Betlejem w 386 roku. Podejmuje na nowo studia filologiczne, zakotwiczone w konkretnych miejscach, które były scenerią studiowanych opowiadań.

Znaczenie przypisywane miejscom świętym jest podkreślone nie tylko przez jego wybór życia w Palestynie, od 386 roku aż do śmierci, ale także przez posługę dla pielgrzymek. Właśnie w Betlejem, miejscu dla niego uprzywilejowanym, w pobliżu Groty Narodzenia Pańskiego, zakłada dwa „bliźniacze” klasztory, męski i żeński, z hospicjami dla pielgrzymów, którzy przybywają do miejsc świętych i okazuje tym samym swoją wielkoduszność w goszczeniu tych, którzy odwiedzali tę ziemię, by zobaczyć i dotknąć miejsc historii zbawienia, łącząc w ten sposób poszukiwania kulturowe i duchowe ${ }^{12}$.

To właśnie wsłuchując się w Pismo święte, Hieronim odnajduje samego siebie, oblicze Boga i oblicze swoich braci, oraz udoskonala swoje upodobanie do życia wspólnotowego. Stąd jego pragnienie, by żyć z przyjaciółmi, jak za czasów Akwilei, i zakładać wspólnoty monastyczne, realizując cenobityczny ideał życia zakonnego, gdzie klasztor postrzega się jako „siłownię”, w której kształtuje się ludzi, „którzy ze wszystkich byli najmniejsi, aby mogli być ze wszystkich pierwszymi”, szczęśliwych w ubóstwie i zdolnych do nauczania swoim sposobem życia. Uważa, że życie ,poddane kierownictwu jednego ojca w towarzystwie wielu", ma znaczenie formacyjne, aby nauczyć się pokory, cierpliwości, milczenia i łagodności, świadomości, że „,prawda nie lubi kątów i nie szuka zauszników”" Wyznaje też, że „tęskni za celami klasztoru, [...] pragnie naśladować gorliwość tych mrówek, gdzie pracuje się wspólnie i gdzie nie istnieje nic, co byłoby czyjąkolwiek własnością, lecz wszystko należy do wszystkich"14.

Hieronim nie szuka $\mathrm{w}$ studium przelotnego zadowolenia jako celu samego w sobie, ale traktuje je jako ćwiczenie życia duchowego, środek dotarcia do Boga. Zatem również jego formacja klasyczna zostaje podporządkowana bardziej dojrzałej służbie dla wspólnoty kościelnej. Pomyślmy o pomocy udzielonej papieżowi Damazemu, o nauczaniu, które głosił kobietom, zwłaszcza w języku hebrajskim, od pierwszego kręgu na

12 Por. VD 89, AAS 102 (2010) s. 761-762.

13 Por. Hieronymus, Ep. 125, 9.15.19, CSEL 56, 128.133-134.139; Św. Hieronim, Żywoty Mnichów, przekł. B. Degórski, Kraków-Tyniec 1995, s. 190.

14 Hieronymus, Vita Malchi monachi captivi 7, 3: PL 23, 59-60; Opere storiche e agiografiche, a cura di B. Degórski, Opere di Girolamo XV, Roma 2014, s. 196-199. 
Awentynie, do tego stopnia, że Paula i Eustochia weszły w ,zmagania tłumaczy" 15 i, co było wówczas niesłychane — miały zapewnione możliwości czytania i śpiewania Psalmów w języku oryginału ${ }^{16}$.

Jego kultura zostaje oddana na służbę i jest przywoływana jako niezbędna dla każdego ewangelizatora. Tak oto przypomina swojemu przyjacielowi Nepocjanowi: „Mowa kapłanów niech się opiera na czytaniu Pisma świętego. Chcę, żebyś był nie deklamatorem, krzykaczem plotącym bez sensu, ale świadomym tajemnicy (mysterii) i w sakramentach (sacramentorum) Boskich bardzo wykształconym. Potokiem słów i szybkością mowy wywoływać podziw u niedoświadczonego pospólstwa jest oznaką ludzi nieuczonych. Człowiek bezczelny thumaczy często to, czego sam nie wie, a przekonawszy innych, sobie również przypisuje wiedzę"17.

W Betlejem, aż do swej śmierci w 420 roku, Hieronim przeżywa najbardziej owocny i intensywny okres swego życia, całkowicie oddany studium Pisma świętego, zaangażowany w monumentalne dzieło przekładu całego Starego Testamentu z oryginału hebrajskiego. Jednocześnie komentuje księgi prorockie, Psalmy, dzieła św. Pawła i pisze podręczniki do studiowania Biblii. Cenna praca zespolona w jego dziełach, jest owocem konfrontacji i współpracy, od kopiowania i zestawiania ze sobą manuskryptów, po refleksję i dyskusję: „Nigdy nie ufałem własnym siłom, by studiować tomy Boże, [...] mam w zwyczaju zadawać pytania, nawet odnośnie do tego, co, jak sądziłem, wiedziałem, a tym bardziej odnośnie do tego, czego nie byłem pewien"18. Zdając sobie zatem sprawę z własnych ograniczeń, prosi o nieustanne wsparcie w modlitwie wstawienniczej w intencji powodzenia jego przekładu tekstów świętych „,w tym samym Duchu, w którym zostały napisane" 19 , nie zapominając również o przekładaniu dzieł autorów niezbędnych dla pracy egzegetycznej, takich jak Orygenes, aby „dostarczyć materiału tym, którzy pragną czynić postępy w poznaniu rzeczy”20.

Studium Hieronima ukazuje się jako wysiłek podejmowany we wspólnocie i w służbie dla wspólnoty, będąc wzorcem synodalności również dla nas, dla naszych czasów i dla różnych instytucji kulturalnych Kościoła, tak aby zawsze były „miejscem, gdzie wiedza staje się służbą, gdyż bez wiedzy, która rodzi się ze współpracy i prowadzi do współdziałania, nie ma praw-

\footnotetext{
15 Hieronymus, Pref. Esther 2, PL 28, 1505.

16 Por. Hieronymus, Ep. 108, 26, CSEL 55, 344-345.

17 Hieronymus, Ep. 52, 8: CSEL 54, 428-429. Por. VD 60, AAS 102 (2010) s. 739.

18 Hieronymus, Pref. Paralipomenon LXX, 1.10-15, SCh 592, 340.

19 Hieronymus, Pref. in Pentateuchum, PL 28, 184.

20 Hieronymus, Ep. 80, 3, CSEL 55, 105.
} 
dziwego i integralnego rozwoju ludzkiego"21. Fundamentem tej komunii jest Pismo święte, którego nie możemy czytać sami: „Biblia została napisana przez lud Boży i dla ludu Bożego, pod natchnieniem Ducha Świętego. Jedynie w tej komunii z ludem Bożym możemy rzeczywiście dotrzeć z naszym «my» do istoty prawdy, którą Bóg chce nam przekazać"22.

Solidne doświadczenie życia, karmione słowem Bożym, sprawia, że Hieronim, za sprawą obszernej wymiany korespondencji, staje się przewodnikiem duchowym. Staje się towarzyszem w drodze, przekonany, że „,nie ma takiej sztuki, której można by się nauczyć bez mistrza”, jak pisze do Rustyka: „wszystko to pragnę ci wpoić, trzymając cię za rękę, podobnie jak doświadczony marynarz po wielu zatonięciach usiłuje pouczyć niedoświadczonego żeglarza"23. Z tego spokojnego zakątka świata śledzi ludzkość w epoce wielkich wstrząsów, naznaczonej wydarzeniami takimi jak złupienie Rzymu w 410 roku, które głęboko go poruszyło.

W listach prowadzi spory doktrynalne, zawsze broniąc prawdziwej wiary, okazując się człowiekiem relacji przeżywanych z mocą i łagodnością, z pełnym zaangażowaniem, bez form przesłodzonych, doświadczając, że „umiłowanie nie ma ceny” 24 . W ten sposób przeżywa on swoje uczucia z ożywieniem i szczerością. To zaangażowanie w sytuacje, w których żyje i pracuje, przejawia się również w tym, że ofiaruje swoją pracę tłumacza i komentatora jako munus amicitiae [posługę przyjaźni]. Jest to przede wszystkim dar dla przyjaciół, odbiorców i adresatów jego dzieł, których prosi, by czytali je raczej przyjaznym niż krytycznym okiem, a następnie dla czytelników, jemu współczesnych i wszystkich czasów ${ }^{25}$.

Ostatnie lata życia spędza na osobistej i wspólnotowej modlitewnej lekturze Pisma świętego, na kontemplacji, w służbie braciom poprzez swoje dzieła. Wszystko to w Betlejem, obok groty, w której Dziewica zrodziła Słowo, ze świadomością, że „szczęśliwy, kto w swoim sercu nosi krzyż, zmartwychwstanie, miejsce narodzenia Chrystusa i miejsce Jego wniebowstąpienia! Szczęśliwy, kto w swoim sercu ma Betlejem i w czyim sercu Chrystus rodzi się każdego dnia!"26.

21 Franciszek, Messaggio in occasione della XXIV solenne Seduta pubblica delle Pontificie Accademie (4 grudnia 2019), „L'Osservatore Romano”, 6 grudnia 2019, s. 8.

22 VD 30, AAS 102 (2010) s. 709.

23 Hieronymus, Ep. 125, 15.2, CSEL 56, 133.120.

24 Hieronymus, Ep. 3, 6, CSEL 54, 18.

25 Hieronymus, Pref. Josue, 1, 9-12, SCh 592, 316.

26 Hieronymus, Homilia in Psalmum 95, PL 26, 1181. Por. Orygenes - Hieronim, Homilie o Księdze Psalmów, przekł. S. Kalinkowski, Kraków 2004, s. 155. 


\section{Klucz mądrościowy do jego portretu}

Dla pełnego zrozumienia osobowości św. Hieronima konieczne jest połączenie dwóch charakterystycznych wymiarów jego egzystencji jako człowieka wierzącego: $z$ jednej strony absolutne i bezwzględne poświęcenie się Bogu, z wyrzeczeniem się wszelkich przyjemności ludzkich dla miłości Chrystusa ukrzyżowanego (por. 1Kor 2,2; Flp 3,8.10); z drugiej zaś strony, trud wytrwałego studiowania, ukierunkowanego wyłącznie na coraz pełniejsze rozumienie tajemnicy Pana. I właśnie to podwójne świadectwo, składane po mistrzowsku przez Hieronima, jest proponowane jako wzór: przede wszystkim dla mnichów, by ci, którzy żyją ascezą i modlitwą, byli zachęcani do oddania się żmudnej pracy badawczej i intelektualnej; potem dla uczonych, którzy muszą pamiętać, że wiedza jest wartościowa pod względem religijnym tylko wówczas, gdy opiera się na wyłącznym umiłowaniu Boga, na ogołoceniu z wszelkich ambicji ludzkich i wszelkich dążeń światowych.

Wymiary takie znalazły wyraz w historii sztuki, w której św. Hieronim jest często obecny: wielcy mistrzowie malarstwa zachodniego pozostawili nam jego podobizny. Możemy wyodrębnić gatunki ikonograficzne według dwóch odrębnych sposobów przedstawiania go. Jeden przedstawia go przede wszystkim jako mnicha i pokutnika, z ciałem wyrzeźbionym postem, ukrytego na terenach pustynnych, klęczącego lub leżącego krzyżem na ziemi, w wielu przypadkach ściskającego w prawej ręce kamień, żeby bić się w pierś, i z oczami zwróconymi ku Ukrzyżowanemu. W tę linię wpisuje się wzruszające arcydzieło Leonarda da Vinci zachowane w Pinakotece Watykańskiej. Inny sposób przedstawienia Hieronima, to ukazanie go jako uczonego, siedzącego przy biurku, zamierzającego tłumaczyć i komentować Pismo święte, otoczonego woluminami i zwojami, zaangażowanego $\mathrm{w}$ misję obrony wiary poprzez myśl i pismo. W tej postawie - by zacytować inny znakomity przykład — przedstawiał go niejednokrotnie Albrecht Dürer.

Dwa przywołane wyżej aspekty można znaleźć złączone ze sobą na płótnie Caravaggia, w Gallerii Borghese w Rzymie: w tej samej scenie jest bowiem przedstawiony stary asceta, niedbale okryty czerwoną tkaniną, który trzyma na stole czaszkę, symbol próżności spraw doczesnych; ale jednocześnie mocno ukazany jest także charakter uczonego, którego oczy utkwione są w księdze, podczas gdy jego ręka zanurza pióro w kałamarzu, w geście charakterystycznym dla pisarza.

W podobny sposób - który nazwałbym mądrościowym — musimy rozumieć podwójny profil drogi życiowej Hieronima. Kiedy jako prawdzi- 
wy „Lew Betlejemski” przesadzał w tonie swoich wypowiedzi, czynił to w poszukiwaniu prawdy, której był gotów stać się bezwarunkowym sługą.

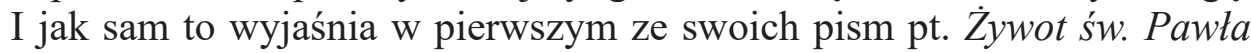
tebańskiego, pustelnika, lwy są zdolne do „potężnych ryków”, ale także do łez ${ }^{27}$. Z tego powodu to, co pojawia się w jego postaci jako dwie przeciwstawne cechy, to w istocie elementy, z pomocą których Duch Święty pozwolił mu na dojrzewanie w wewnętrznej jedności.

\section{Umiłowanie Pisma świętego}

Szczególną cechą osobowości duchowej św. Hieronima pozostaje bez wątpienia jego żarliwe umiłowanie słowa Bożego, przekazanego Kościołowi w Piśmie świętym. O ile wszyscy doktorzy Kościoła a w szczególności ci z pierwszych wieków chrześcijaństwa - wyraźnie czerpali treść swego nauczania z Biblii, to Hieronim czynił to w sposób bardziej systematyczny i w pewnym sensie wyjątkowy.

W ostatnich czasach egzegeci odkryli narracyjny i poetycki geniusz Biblii, podkreślany właśnie ze względu na jej wyrazistość. Natomiast Hieronim podkreślił w Piśmie świętym raczej pokorny charakter objawiania się Boga, wyrażony w surowej i niemal prymitywnej naturze języka hebrajskiego, w porównaniu z wyrafinowaniem łaciny cyceroniańskiej. Poświęcił się więc Pismu świętemu nie ze względu na gust estetyczny, ale - jak dobrze wiadomo - tylko dlatego, że prowadziło go ono do poznania Chrystusa, ponieważ nieznajomość Pisma świętego jest nieznajomością Chrystusa ${ }^{28}$.

Hieronim uczy nas, że nie tylko Ewangelie powinny być studiowane, i nie tylko tradycja apostolska, obecna w Dziejach Apostolskich i Listach, powinna być komentowana, ponieważ cały Stary Testament jest niezbędny do wniknięcia w prawdę i bogactwo Chrystusa ${ }^{29}$. Świadczą o tym same karty Ewangelii: mówią nam o Jezusie jako Nauczycielu, który, aby wyjaśnić swoją tajemnicę, odwołuje się do Mojżesza, proroków i Psalmów (por. Łk 4,16-21; 24,27.45-47). Także przepowiadanie Piotra i Pawła w Dziejach Apostolskich jest również znacząco zakorzenione w Piśmie

27 Por. Hieronymus, Vita S. Pauli primi eremitae 16, 2, PL 23, 28; Opere storiche e agiografiche, dz. cyt., s. 111.

28 Por. Hieronymus, In Isaiam Prol., PL 24, 17; Św. Hieronim, Komentarz do Księgi Izajasza. Prolog, CCL 73, Turnholti 1963, s. 1: „Ignoratio Scripturarum, ignoratio Christi est”, thum. według: Liturgia Godzin, t. 4, Poznań 1988, s. 1226.

29 Por. Sobór Watykański II, Konstytucja dogmatyczna Dei Verbum 14. 
świętym Starego Testamentu; bez nich nie można w pełni zrozumieć postaci Syna Bożego, Mesjasza Zbawiciela. Starego Testamentu nie należy uważać za obszerny wykaz cytatów, które udowadniają wypełnienie się proroctw w osobie Jezusa $\mathrm{z}$ Nazaretu. Natomiast — bardziej radykalnie — jedynie w świetle postaci starotestamentalnych można w pełni poznać sens wydarzenia Chrystusa, dokonanego w Jego śmierci i zmartwychwstaniu. Stąd potrzeba ponownego odkrycia w praktyce katechetycznej i kaznodziejskiej, a także w traktatach teologicznych, niezbędnego wkładu Starego Testamentu, który należy odczytywać i przyswajać jako cenny pokarm (por. Ez 3,1-11; Ap 10,8-11) ${ }^{30}$.

Całkowite poświęcenie się Hieronima Pismu świętemu przejawia się w żarliwej formie wyrazu, podobnej do starożytnych proroków. To od nich nasz Doktor czerpie wewnętrzny ogień, który staje się słowem żywiołowym i wstrząsającym (por. Jr 5,14; 20,9; 23,29; Ml 3,2; Syr 48,1; Mt 3,11; Łk 12,49), koniecznym do wyrażenia żarliwej gorliwości sługi dla sprawy Bożej. W ślad za Eliaszem, Janem Chrzcicielem, a także Apostołem Pawłem, oburzenie kłamstwem, obłudą i fałszywymi doktrynami rozpala dyskurs Hieronima, czyniąc go prowokacyjnym i pozornie srogim. Polemiczny wymiar jego pism jest lepiej rozumiany, gdy czyta się je jako rodzaj zapożyczenia i urzeczywistnienia najbardziej autentycznej tradycji prorockiej. Hieronim jest zatem wzorcem nieustępliwego świadectwa prawdy, które sięga po surowość wyrzutów, by doprowadzić do nawrócenia. W intensywności wyrażeń i obrazów przejawia się odwaga sługi, który nie chce się przypodobać ludziom, ale wyłącznie swojemu Panu (por. Ga 1,10), dla którego strawił całą energię duchową.

\section{Studium Pisma świętego}

Namiętna miłość św. Hieronima do Pisma świętego przepojona jest posłuszeństwem. Przede wszystkim wobec Boga, który wyraził Siebie słowami wymagającymi słuchania pełnego $\mathrm{czci}^{31}$, a w konsekwencji posłuszeństwa również wobec tych, którzy w Kościele reprezentują żywą tradycję interpretacji orędzia objawionego. „Posłuszeństwo wierze” (Rz 1,5; 16,26) nie jest jednak jedynie biernym odbiorem tego, co jest znane. Wręcz przeciwnie, wymaga ono czynnego zaangażowania w osobiste poszukiwanie.

\footnotetext{
30 Por. Sobór Watykański II, Konstytucja dogmatyczna Dei Verbum 14.

31 Por. Sobór Watykański II, Konstytucja dogmatyczna Dei Verbum 7.
} 
Można uznać św. Hieronima za wiernego i pracowitego „sługę Słowa, całkowicie oddanego krzewieniu wśród swoich braci w wierze bardziej adekwatnego rozumienia powierzonego im świętego „depozytu” (por. $1 \mathrm{Tm} 6,20 ; 2 \mathrm{Tm} 1,14)$. Bez zrozumienia tego, co zostało napisane przez natchnionych autorów, samo słowo Boże pozbawione jest skuteczności (por. Mt 13,19), i nie może wypływać zeń miłość do Boga.

Jednakże karty biblijne nie zawsze są bezpośrednio dostępne. Jak mówi Księga Izajasza $(29,11)$, nawet dla tych, którzy potrafią ,czytać” — to znaczy, którzy mają wystarczającą formację intelektualną — święta księga wydaje się ,zapieczętowana”, hermetycznie zamknięta dla interpretacji. Trzeba zatem, aby wkroczył kompetentny świadek i przyniósł uwalniający klucz, klucz Chrystusa Pana, jedynego, który może złamać pieczęcie i otworzyć księgę (por. Ap 5,1-10), aby odsłonić cudowne wylanie łaski (por. Łk 4,17-21). Wielu, nawet wśród praktykujących chrześcijan, otwarcie deklaruje, że nie umie czytać (por. Iz 29,12), nie z powodu analfabetyzmu, lecz dlatego, że nie są przygotowani do rozumienia języka biblijnego, jego sposobów wyrażania i starożytnych tradycji kulturowych, wobec czego tekst biblijny okazuje się nieczytelny, jakby był napisany w nieznanym alfabecie i w niezrozumiałym języku.

Konieczne jest zatem pośrednictwo tłumacza, który wypełniałby swoją funkcję „diakonalną”, oddając się na służbę tym, którzy nie mogą zrozumieć znaczenia tego, co zostało proroczo napisane. Można w tym względzie przywołać obraz diakona Filipa, którego Pan pobudził do spotkania z eunuchem, który czytał Izajasza $(53,7-8)$ na swoim rydwanie, ale nie miał możliwości zrozumienia sensu tego tekstu. „Czy ty rozumiesz, co czytasz?”, zapytał Filip, a eunuch odpowiedział: „Jakżeż mogę [rozumieć], jeśli mi nikt nie wyjaśni?” (Dz 8,30-31) 32. $^{32}$

Hieronim jest naszym przewodnikiem ponieważ, podobnie jak Filip (por. Dz 8,35), prowadzi każdego czytelnika do tajemnicy Jezusa, jak i dlatego, że w sposób odpowiedzialny i systematyczny podejmuje pośrednictwo egzegetyczne i kulturowe niezbędne do poprawnego i owocnego odczytywania Pisma świętego ${ }^{33}$. Kompetencje w dziedzinie języków, w których zostało przekazane słowo Boże, uważna analiza i ocena rękopisów, systematyczne badania archeologiczne, jak również znajomość historii interpretacji, jednym słowem wszystkie narzędzia metodologiczne, które były dostępne w jego epoce historycznej, były przez niego wykorzysty-

32 Por. Hieronymus, Ep. 53, 5, CSEL 54, 451: Le lettere, red. S. Cola, II, Roma 1997, s. 54.

33 Por. Sobór Watykański II, Konstytucja dogmatyczna Dei Verbum 12. 
wane stosownie i mądrze, by zwrócić się ku właściwemu zrozumieniu natchnionego Pisma.

Taki wzorcowy wymiar działalności św. Hieronima jest niezwykle ważny także w Kościele dnia dzisiejszego. Jeśli, jak naucza nas Dei Verbum, Biblia jest „niejako duszą świętej teologii” ${ }^{44}$ i jakby duchową kwintesencją chrześcijańskiej praktyki religijnej ${ }^{35}$, konieczne jest, aby interpretowanie Biblii było wsparte specyficznymi umiejętnościami.

Temu celowi służą z pewnością ośrodki doskonalenia badań biblijnych (jak Papieski Instytut Biblijny w Rzymie, a w Jerozolimie École Biblique i Studium Biblicum Franciscanum) oraz patrystycznych (jak Augustinianum w Rzymie), ale również każdy wydział teologiczny musi się starać, żeby nauczanie Pisma świętego było zaprogramowane w taki sposób, żeby zapewnić studentom kompetentne umiejętności interpretacji, zarówno w egzegezie tekstów, jak i w syntezie teologii biblijnej. Bogactwo Pisma świętego jest niestety przez wielu nieznane lub pomniejszane, ponieważ nie zapewniono im niezbędnych podstaw wiedzy. Dlatego też, oprócz zwiększenia liczby studiów kościelnych dla kapłanów i katechetów, które lepiej wykorzystywałyby kompetencje w zakresie rozumienia Pisma świętego, należy promować formację obejmującą wszystkich chrześcijan, tak aby każdy z nich mógł otworzyć świętą księgę i czerpać z niej bezcenne owoce mądrości, nadziei i życia ${ }^{36}$.

W tym miejscu chciałbym przypomnieć to, co mój Poprzednik wyraził w adhortacji apostolskiej Verbum Domini: „Sakramentalność słowa staje się zatem zrozumiała przez analogię do rzeczywistej obecności Chrystusa pod konsekrowanymi postaciami chleba i wina. [...] Na temat sposobu, w jaki należy odnosić się zarówno do Eucharystii, jak i słowa Bożego, św. Hieronim pisze: «Czytamy Pisma święte. Myślę, że Ewangelia jest ciałem Chrystusa; myślę, że Pisma święte to Jego nauczanie. A kiedy On mówi: Jeżeli nie będziecie jedli Ciała Syna Człowieczego ani pili Krwi Jego (J 6,53), to chociaż te słowa można rozumieć w odniesieniu do Tajemnicy [eucharystycznej], niemniej jednak ciało Chrystusa i Jego krew są prawdziwie słowem Pisma, są nauczaniem Bożym»" ${ }^{37}$.

Niestety, w wielu rodzinach chrześcijańskich nikt nie czuje się zdolny — jak to zostało natomiast zapisane w Torze (por. Pwt 6,6) — do przeka-

34 Sobór Watykański II, Konstytucja dogmatyczna Dei Verbum 24.

35 Por. Sobór Watykański II, Konstytucja dogmatyczna Dei Verbum 25.

36 Por. Sobór Watykański II, Konstytucja dogmatyczna Dei Verbum 21.

37 Nr 56. Por. Hieronymus, In Psalmum 147, CCL 78, 337-338; S. Girolamo, 59 Omelie sui Salmi (119-149), red. A. Capone, Opere di Girolamo IX/2, Roma 2018, s. 171. 
zania swoim dzieciom słowa Bożego, z całym jego pięknem, z całą jego mocą duchową. $Z$ tego powodu ustanowiłem Niedzielę Słowa Bożego ${ }^{38}$, zachęcając do modlitewnego czytania Biblii i poznawania słowa Bożego ${ }^{39}$. Każdy inny wyraz religijności będzie dzięki temu ubogacony sensem, będzie umiejscowiony w hierarchii wartości i będzie ukierunkowany na to, co stanowi szczyt wiary: pełne przylgnięcie do tajemnicy Chrystusa.

\section{Wulgata}

„Najsłodszym owocem żmudnego siewu"40 studiowania języka greckiego i hebrajskiego, dokonanego przez Hieronima, jest thumaczenie Starego Testamentu na język łaciński, na podstawie oryginału hebrajskiego. Do tego czasu chrześcijanie Cesarstwa Rzymskiego mogli czytać całą Biblię jedynie w języku greckim. Podczas gdy księgi Nowego Testamentu zostały napisane w języku greckim, dla ksiąg starotestamentowych istniała pełna wersja, tak zwana Septuaginta (czyli wersja siedemdziesięciu), opracowana przez wspólnotę żydowską Aleksandrii ok. II w. przed Chrystusem. Dla czytelników posługujących się łaciną, w ich języku nie było jednak pełnej wersji Biblii, a jedynie kilka częściowych i niepełnych tłumaczeń z języka greckiego. Zasługą Hieronima, a następnie jego spadkobierców, jest podjęcie rewizji i nowego przekładu całego Pisma świętego. Po rozpoczęciu w Rzymie, za zachętą papieża Damazego, poprawiania tłumaczenia Ewangelii i Psalmów, Hieronim podjął w swojej samotni w Betlejem thumaczenie wszystkich ksiąg starotestamentowych, bezpośrednio z języka hebrajskiego: dzieło, które trwało latami.

Do wykonania tej pracy tłumaczeniowej Hieronim wykorzystał swoją znajomość języka greckiego i hebrajskiego, a także solidne wykształcenie łacińskie, oraz posłużył się narzędziami filologicznymi, jakimi dysponował, w szczególności Hexapla Orygenesa. Ostateczny tekst łączył w sobie kontynuację formuł, które weszły już do powszechnego użytku, z większą wiernością oryginałowi hebrajskiemu, nie rezygnując $z$ elegancji języka łacińskiego. W rezultacie powstał prawdziwy pomnik, który naznaczył historię kultury Zachodu, kształtując jego język teologiczny. Tłumaczenie

38 Por. Franciszek, List apostolski w formie Motu proprio Aperuit illis (30 września 2019).

39 Por. Franciszek, Adhortacja apostolska Evangelii gaudium 152.175, AAS 105 (2013) s. 1083-1084.1093.

40 Por. Hieronymus, Ep. 52, 3, CSEL 54, 417. 
Hieronima, po przezwyciężeniu pewnych początkowych odrzuceń, od razu stało się wspólnym dziedzictwem zarówno uczonych, jak i ludu chrześcijańskiego, stąd jego nazwa Wulgata ${ }^{41}$. Europa w średniowieczu nauczyła się czytać, modlić się i rozumować, korzystając ze stron Biblii przetłumaczonej przez Hieronima. „Pismo święte stało się zatem swego rodzaju «ogromnym słownikiem» (P. Claudel) i «atlasem ikonograficznym» (M. Chagall), z którego czerpała chrześcijańska kultura i sztuka"42. Literatura, sztuka, a nawet język potoczny nieustannie czerpały z Hieronimowej wersji Biblii, pozostawiając nam kolejne skarby piękna i pobożności.

To właśnie z uwagi na ten niepodważalny fakt Sobór Trydencki określił w dekrecie Insuper ,autentyczny” charakter Wulgaty, oddając hołd wielowiekowemu wykorzystywaniu jej przez Kościół, i potwierdzając jej wartość jako narzędzia do studiowania, kaznodziejstwa i publicznych dysput $^{43}$. Nie oznaczało to jednak umniejszania znaczenia języków oryginalnych, ponieważ Hieronim nie tylko nie zakazywał podejmowania w przyszłości nowych przedsięwzięć w zakresie pełnego tłumaczenia, ale też nieustannie o nich przypominał. Św. Paweł VI, z upoważnienia Ojców Soboru Watykańskiego II, chciał, aby prace nad rewizją tłumaczenia Wulgaty zostały zakończone i udostępnione całemu Kościołowi. I tak oto św. Jan Paweł II w Konstytucji apostolskiej Scripturum thesaurus ${ }^{44}$ ogłosił w 1979 roku wydanie typiczne zwane Neowulgata.

\section{Thumaczenie jako inkulturacja}

Poprzez to tłumaczenie Hieronimowi udało się ,,inkulturować” Biblię do języka i kultury łacińskiej, a ta jego praca stała się trwałym wzorcem dla działania misyjnego Kościoła. Istotnie, , gdy jakaś wspólnota przyjmuje orędzie zbawienia, Duch Święty zapładnia jej kulturę przemieniającą mocą Ewangelii" ${ }^{45}$ i w ten sposób powstaje swego rodzaju obieg zamknięty: tak jak tłumaczenie Hieronima jest dłużnikiem języka i kultury klasyków łacińskich, których ślady są wyraźnie widoczne, tak i ono, wraz ze swoim językiem i swoją treścią symboliczną i wyobraźnią, stało się z kolei twórczym elementem kultury.

\footnotetext{
41 Por. VD 72, AAS 102 (2010) s. 746-747.

42 Św. Jan Paweł II, List do artystów (4 kwietnia 1999) 5, AAS 91 (1999) s. 1159-116.

43 Por. Denzinger-Schönmetzer, Enchiridion Symbolorum, 1506.

4425 kwietnia 1979, AAS LXXI (1979) s. 557-559.

45 Franciszek, Adhortacja apostolska Evangelii gaudium 116, AAS 105 (2013) s. 1068.
} 
Dzieło translatorskie Hieronima uczy nas, że pozytywne wartości i formy każdej kultury stanowią ubogacenie dla całego Kościoła. Różne sposoby, w jakie słowo Boże jest głoszone, rozumiane i przeżywane w każdym nowym tłumaczeniu, ubogacają samo Pismo święte, ponieważ według znanego wyrażenia Grzegorza Wielkiego wzrasta ono wraz z czytelnikiem $^{46}$, otrzymując na przestrzeni wieków nowe akcenty i nowe brzmienia. Włączenie Biblii i Ewangelii do różnych kultur sprawia, że Kościół coraz częściej jawi się jako sponsa ornata monilibus suis (Iz 61,10) [oblubienica strojna w swe klejnoty]. I jednocześnie zaświadcza, że Biblia musi być stale przekładana na język i mentalność każdej kultury i każdego pokolenia, także na globalną zsekularyzowaną kulturę naszych czasów ${ }^{47}$.

Słusznie przypomniano, że możliwe jest wskazanie analogii między tłumaczeniem, jako aktem otwartości językowej, a innymi formami gościnności ${ }^{48}$. $Z$ tego powodu thumaczenie nie jest pracą, która dotyczy jedynie języka, lecz odpowiada $\mathrm{w}$ istocie szerszej decyzji etycznej, która wiąże się z całą wizją życia. Bez tłumaczenia różne wspólnoty językowe nie byłyby w stanie porozumieć się ze sobą; zamknęlibyśmy jedni przed drugimi bramy historii i zaprzeczylibyśmy możliwości budowania kultury spotkania $^{49}$. Bez thumaczenia bowiem, nie udziela się gościnności, a wręcz przeciwnie, umacniają się praktyki wrogości. Tłumacz jest budowniczym mostów. Ileż pochopnych sądów, ile potępień i konfliktów wynika z tego, że nie znamy języka innych i nie przykładamy się, z wytrwałą nadzieją, do tej niekończącej się próby miłości, jaką jest tłumaczenie!

Także Hieronim musiał przeciwstawić się dominującej myśli swoich czasów. Podczas gdy u zarania Cesarstwa Rzymskiego znajomość języka greckiego była stosunkowo powszechna, w jego czasach była już ona rzadkością. On jednak stał się jednym z najlepszych znawców języka greckiego i chrześcijańskiej literatury greckiej, a podjął jeszcze bardziej żmudną, samotną podróż, kiedy poświęcił się studium języka hebrajskiego. Jeśli, jak zostało napisane, ,granice mego języka wskazują granice mego świata"50, to możemy powiedzieć, że wielojęzyczności św. Hieronima zawdzięczamy

\footnotetext{
46 Gregorius Magnus, Homilia in Ezechielem I 7, PL 76, 843D.

47 Por. Franciszek, Adhortacja apostolska Evangelii gaudium 116, AAS 105 (2013) s. 1068.

48 Por. P. Ricoeur, O ttumaczeniu, Gdańsk 2008.

49 Por. Franciszek, Adhortacja apostolska Evangelii gaudium 24, AAS 105 (2013) s. $1029-1030$.
}

50 L. Wittgenstein, Tractatus Logico-Philosophicus 5.6, przekł. B. Wolniewicz, Warszawa 1970. 
bardziej powszechne rozumienie chrześcijaństwa, a jednocześnie bardziej spójne z jego źródłami.

Wraz z obchodami kolejnego stulecia śmierci św. Hieronima, nasze spojrzenie zwraca się ku niezwykłej żywotności misyjnej wyrażonej przez tłumaczenie słowa Bożego na ponad trzy tysiące języków. Wielu misjonarzom zawdzięczamy cenne dzieło, polegające na publikowaniu gramatyk, słowników i innych narzędzi językowych, które dają podstawy ludzkiej komunikacji i są nośnikiem „misyjnego marzenia o dotarciu do wszystkich" ${ }^{51}$. Należy docenić całą tę pracę i w nią zainwestować, przyczyniając się do przezwyciężenia granic niekomunikatywności i braku spotkania. Jest jeszcze wiele do zrobienia. Jak już powiedziano, nie ma zrozumienia bez tłumaczenia ${ }^{52}$ : nie zrozumielibyśmy ani siebie samych, ani też innych.

\section{Hieronim a Stolica Piotrowa}

Hieronim miał zawsze szczególny stosunek do Rzymu: Rzym był duchowym portem, do którego nieustannie powracał; w Rzymie uformował się jako humanista i ukształtował jako chrześcijanin; jest homo romanus. Ta więź odzwierciedla się w bardzo szczególny sposób, w języku tego Miasta, łacinie, której był mistrzem i miłośnikiem, ale przede wszystkim jest związana z Kościołem Rzymskim, a w szczególności ze Stolicą Piotrową. Tradycja ikonograficzna, w sposób anachroniczny przedstawia go w purpurze kardynalskiej, aby wskazać jego przynależność do prezbiterium Rzymu u boku papieża Damazego. To właśnie w Rzymie rozpoczęła się rewizja tłumaczenia przygotowanego przez Hieronima. I nawet kiedy zazdrość i niezrozumienie zmusiły go do opuszczenia miasta, zawsze pozostawał mocno związany ze Stolicą Piotrową.

Dla Hieronima Kościół Rzymski jest żyzną glebą, na której ziarno Chrystusa przynosi obfite owoce ${ }^{53}$. W burzliwych czasach, w których niepodzielną tunikę Kościoła często rozdzierały podziały między chrześcijanami, Hieronim spoglądał na Stolicę Piotrową jako na pewny punkt odniesienia: „Ja postępując tylko za Chrystusem, łączę się w komunii ze Stolicą Piotra. Wiem, że na tej Opoce zbudowany jest Kościół". W pełni sporów z arianami napisał do Damazego: „Ktokolwiek nie gromadzi z Tobą, rozprasza, kto nie

51 Franciszek, Adhortacja apostolska Evangelii gaudium 31, AAS 105 (2013) s. 1033.

52 Por. G. Steiner, Po wieży Babel: problemy języka i przekładu, przekł.

O. i W. Kubińscy, Warszawa 2018.

53 Por. Hieronymus, Ep. 15, 1, CSEL 54, 63. 
należy do Chrystusa, należy do Antychrysta" ${ }^{54}$. Dlatego też może również powiedzieć: „Z tym trzymam, kto jednoczy się ze stolicą Piotra"55.

Hieronim często angażował się w ostre spory z powodu wiary. Jego umiłowanie prawdy i jego żarliwa obrona Chrystusa być może doprowadziły go do przesady w słownej gwałtowności w jego listach i pismach. Był on jednak nastawiony pokojowo: „Chcę pokoju i nie tylko chcę, lecz o niego proszę, ale o pokój Chrystusowy, pokój prawdziwy, pokój bez nieprzyjaźni, pokój, w którym by nie było ukrytej wojny, pokój który by nie ujarzmiał ludzi jako przeciwników, lecz łączył jako przyjaciół"56.

Nasz świat potrzebuje bardziej niż kiedykolwiek lekarstwa, jakim jest miłosierdzie i jedność. Pozwólcie, że powtórzę raz jeszcze: dawajmy świadectwo braterskiej komunii, które stanie się pociągające i oświecające ${ }^{57}$. „Po tym wszyscy poznają, żeście uczniami moimi, jeśli będziecie się wzajemnie miłowali" (J 13,35). O to właśnie Jezus prosił Ojca w przejmującej modlitwie: ,aby wszyscy stanowili jedno [...] w nas [...], aby świat uwierzył" (J 17,21).

\section{Umilować to, co milowal Hieronim}

Na zakończenie tego listu chciałbym jeszcze raz skierować apel do wszystkich. Wśród wielu pochwał składanych św. Hieronimowi przez potomnych jest i ta, że nie był on uważany tylko za jednego z największych miłośników owej „biblioteki”, którą karmi się przez cały czas chrześcijaństwo, poczynając od skarbu Pisma świętego. Można do niego odnieść to, co on sam napisał o Nepocjanie: „Przez ciągłe czytanie i długotrwałe rozmyślanie uczynił serce swe biblioteką Chrystusową"58. Hieronim nie szczędził wysiłków, aby wzbogacić swoją bibliotekę, w której zawsze widział laboratorium niezbędne dla zrozumienia wiary i życia duchowego. Także i w tym jest godnym podziwu przykładem dla współczesności. On jednak poszedł dalej. Dla niego studia nie ograniczały się do lat młodzieńczych jego formacji; były stałym zaangażowaniem, priorytetem każdego dnia jego życia. Krótko mówiąc, możemy powiedzieć, że przy-

\footnotetext{
54 Hieronymus, Ep. 15, 2, CSEL 54, 62-64.

55 Hieronymus, Ep. 16, 2, CSEL 54, 69.

56 Hieronymus, Ep. 82, 2, CSEL 55, 109.

57 Por. Franciszek, Adhortacja apostolska Evangelii gaudium 99, AAS 105 (2013) s. 1061.

58 Hieronymus, Ep. 60, 10, CSEL 54, 561.
} 
swoił on całą bibliotekę i stał się szafarzem wiedzy dla wielu innych. Postumian, który w IV wieku podróżował po Wschodzie, aby odkryć ruchy monastyczne, był naocznym świadkiem stylu życia Hieronima, z którym przebywał kilka miesięcy, i tak go opisał: „Pozostaje zawsze zajęty lekturą, cały pogrążony w książkach. Nie spoczywa ani za dnia, ani w nocy; wciąż albo coś czyta albo pisze" 59 .

W związku z tym, często myślę o doświadczeniu, jakie może mieć dziś młody człowiek, wchodząc do księgarni w swoim mieście lub na stronę internetową i szukając tam książek religijnych. Jest to dział, który, jeśli istnieje, w większości przypadków jest nie tylko marginalny, ale brakuje w nim znaczących dzieł. Patrząc na te półki, albo na te strony w sieci, trudno młodemu człowiekowi zrozumieć, że poszukiwania religijne mogą być ekscytującą przygodą, która łączy myśl i serce; że pragnienie Boga rozpalało wielkie umysły na przestrzeni wieków aż do dnia dzisiejszego; że dojrzewanie życia duchowego udzielało się teologom i filozofom, artystom i poetom, historykom i naukowcom. Jednym z dzisiejszych problemów, nie tylko religijnych, jest analfabetyzm: brakuje nam umiejętności hermeneutycznych, które uczyniłyby nas wiarygodnymi tłumaczami naszej własnej tradycji kulturowej. W szczególności chcę rzucić wyzwanie ludziom młodym: wyjdźcie na poszukiwanie waszego dziedzictwa. Chrześcijaństwo czyni was spadkobiercami niezrównanego dziedzictwa kulturowego, które musicie objąć w posiadanie. Bądźcie pasjonatami tej historii, która jest waszą. Ośmielcie się spojrzeć na tego niespokojnego młodzieńca Hieronima, który, jak postać z przypowieści Jezusa, sprzedał wszystko, co posiadał, aby nabyć „drogocenną perłę” (Mt 13,46).

Istotnie, Hieronim jest „Biblioteką Chrystusa”, niewyczerpaną biblioteką, która szesnaście wieków później nadal nas uczy, co oznacza miłość Chrystusa, miłość, która jest nierozerwalnie związana ze spotkaniem z Jego słowem. Z tego powodu obecna rocznica stanowi wezwanie do umiłowania tego, co miłował Hieronim, do ponownego odkrycia jego pism i do tego, by dać się poruszyć wpływem duchowości, którą można opisać w jej najistotniejszym rdzeniu jako niespokojne i pełne pasji pragnienie pełniejszego poznania Boga Objawienia. Jakże nie słuchać w naszych czasach tego, do czego Hieronim nieustannie namawiał swoich współczesnych: „Pismo Boże często czytaj; a raczej świętej lektury nigdy z rąk swych nie wypuszczaj" ${ }^{00}$ ?

59 Sulpicius Severus, Dialogus I, 9, 5, SCh 510, 136-138; Sulpicjusz Sewer, Pisma ośw. Marcinie z Tours. Żywot, Listy, Dialogi, Kraków 1995, s. 119.

60 Hieronymus, Ep. 52, 7, CSEL 54, 426. 
Jaśniejącym przykładem jest Dziewica Maryja, przywoływana przez Hieronima, zwłaszcza w jej dziewiczym macierzyństwie, ale także w Jej postawie rozmodlonej czytelniczki Pisma świętego. Maryja rozważała w swoim sercu (por. Łk 2,19.51), ,ponieważ jako święta czytała Pismo święte i znała proroków, porównywała to, co Jej powiedział anioł Gabriel, z tym, co przepowiedzieli prorocy [...]. Widziała nowonarodzonego swego Syna, swego jedynego Syna, spoczywającego i płaczącego w żłóbku, ale Tym, którego prawdziwie widziała, był Syn Boży. To, co widziała, porównywała z tym, co czytała i słyszała" ${ }^{\text {. }}$. Powierzmy się Jej, która lepiej niż ktokolwiek inny może nas nauczyć jak czytać, rozważać, modlić się i kontemplować Boga niestrudzenie uobecniającego się w naszym życiu.

Rzym, uśw. Jana na Lateranie, dnia 30 września 2020, we wspomnienie św. Hieronima, wósmym roku mego Pontyfikatu.

Franciszek

Copyright $(C)$ by Libreria Editrice Vaticana

${ }^{61}$ Hieronymus, Homilia de nativitate Domini IV, PL Suppl. 2, 191. 